\title{
Adsorption of dyes by ACs prepared from waste tyre reinforcing fibre. Effect of texture, surface chemistry and $\mathrm{pH}$.
}

\author{
Beatriz Acevedo ${ }^{1}$, Raquel P. Rocha², Manuel F.R. Pereira², José L. Figueiredo², Carmen \\ Barriocanal $^{1 *}$ \\ 1. Instituto Nacional del Carbón, INCAR-CSIC, Apartado 73, 33080 Oviedo. Spain \\ 2. Laboratório de Catálise e Materiais (LCM), Laboratório Associado LSRE-LCM, Departamento de \\ Engenharia Química, Faculdade de Engenharia, Universidade do Porto, 4200-465 Porto, Portugal
}

*Corresponding author. Tel: +34 9851190 90; Fax:+34 9852976 62; e.mail address: carmenbr@incar.csic.es

\section{ABSTRACT}

This paper compares the importance of the texture and surface chemistry of waste tyre activated carbons in the adsorption of commercial dyes. The adsorption of two commercial dyes, Basic Astrazon Yellow 7GLL and Reactive Rifafix Red 3BN on activated carbons made up of reinforcing fibres from tyre waste and low-rank bituminous coal was studied. The surface

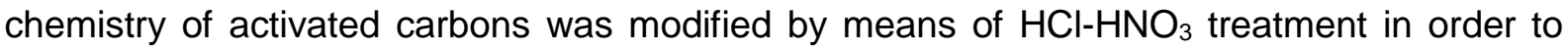
increase the number of functional groups. Moreover, the influence of the $\mathrm{pH}$ on the process was also studied, this factor being of great importance due to the amphoteric characteristics of activated carbons. The activated carbons made with reinforcing fibre and coal had the highest $\mathrm{S}_{\mathrm{BET}}$, but the reinforcing fibre activated carbon samples had the highest mesopore volume. The texture of the activated carbons was not modified upon acid oxidation treatment, unlike their surface chemistry which underwent considerable modification. The activated carbons made with a mixture of reinforcing fibre and coal experienced the largest degree of oxidation, and so had more acid surface groups. The adsorption of reactive dye was governed by the mesoporous volume, while surface chemistry played only a secondary role. However, the surface chemistry of the activated carbons and dispersive interactions played a key role in the adsorption of the basic dye. The adsorption of the reactive dye was more favored in a solution of $\mathrm{pH} 2$, whereas the basic dye was adsorbed more easily in a solution of $\mathrm{pH} 12$.

Keywords: Reinforcing fibre, coal, activated carbons, surface chemistry, $\mathrm{pH}$. 
1. Introduction

Textile wastewaters have a large amount of suspended solids (SS), in addition to COD (chemical oxygen demand), BOD (biochemical oxygen demand), heat, colour, acidity, basicity and other inorganic contaminants. Most pollutants, except colour, can be removed by conventional sewage treatment works (Al-degs et al., 2000). Dyes are difficult to eliminate due to their synthetic origin and complex structure which makes them very stable (Prola et al., 2013).

The presence of even very low concentrations of dyes in effluents is highly visible and undesirable (Nigam et al., 2000). Moreover, their presence reduces aquatic diversity by blocking the passage of light through the water, thereby precluding the photosynthesis of aquatic flora (Al-degs et al., 2000; Cardoso et al., 2011). There is a large variety of dyes (acid, basic, reactive, direct, dispersive, sulphur and metallic dyes) that fall into the cationic, nonionic or anionic category. Direct, acid and reactive dyes are anionic whereas basic dyes are cationic. The highest levels of toxicity have been found in basic and diazo direct dyes (Robinson et al., 2001). However, water soluble reactive and acid dyes are the most problematic since neither conventional biological treatment processes nor physicochemical coagulation/flocculation methods are able to achieve adequate colour removal (Al-degs et al., 2000; Willmott et al., 1998). Reactive dyes are characterised by nitrogen to nitrogen double bonds ( $\mathrm{N}=\mathrm{N}$ azo bonds). Moreover, azo- and nitro-compounds are reduced in sediments to form toxic amines (Weber and Wolfe, 1987).

The most widely used methods of dye removal can be divided into three categories: oxidative processes (Chemical method) such as Fenton's reagent (Ferrero, 2000), ozonation (Hsu et al., 2001; Perkins et al., 1995), photochemical (Paschoal et al., 2009), electrochemical, sodium hypochloride and cucurbituril processes; physical treatments, such as adsorption (Peng et al., 2014; Shoonen and Schoonen 2014), membrane separation (Ciardelli et al., 2000), ion exchange, flocculation (Fang et al., 2010) and electrokinetic coagulation; and biological treatments (Robinson et al., 2000; Srinivasan and Viraraghavan, 2010). All the current methods have their advantages and disadvantages. The adsorption of dyes using activated carbon allows a wide variety of dyes to be eliminated in large scale waste water treatment plants. The disadvantage is its high cost. Nevertheless, this handicap can be circumvented by using low-cost activated carbons made from waste tyre materials (Gupta et al., 2011; Ling and Teng, 2002).

Scrap tyres are converted in tyre recycling plants into tyre crumbs, reinforcing fibre and steel (Acevedo et al.,2013). Tyre crumbs have multiple applications but no use has been found for the reinforcing fibre. The reinforcing fibre is obtained during the process of mechanical grinding of tyres after the metallic parts and the rubber have been removed. These wastes comprise a very heterogeneous material made up of a mixture of microfibre with the 
appearance of a fluff to which pieces of fine rubber are attached and pieces of cord (Acevedo et al., 2015).

This study is aimed at establishing whether the texture or surface chemistry of waste tyre activated carbons is more important for the adsorption of commercial dyes with different polarities. The adsorption of an anionic reactive dye and a basic cationic dye and the influence of $\mathrm{pH}$ on the process are studied.

\section{Materials and methods.}

\subsection{Adsorbate.}

The commercial dyes used in the study were Basic Astrazon Yellow 7GLL (AY) and Reactive Rifafix Red 3BN (RR). These were chosen due to their different types of ionization (cationic and anionic respectively). In addition basic dyes are considered to be more toxic whereas reactive ones are more difficult to remove from effluents. (Figure S1 shows the chemical structure). Distilled water was used to prepare the desired concentration of the dye solutions and a UV-Vis absorption spectrophotometer Jasco V-560 and T60 from PG Instruments Ltd. was employed to measure the concentration of dye at $\lambda_{\max }$ using a calibration curve.

Colour removal from a 1:1 mixture of two dyes and a real textile effluent was carried out using the same procedure. The real textile effluent which was obtained from a raw waste stream after biological treatment in a wastewater treatment plant was used to test the ACs prepared. The $\mathrm{pH}$ of the textile effluent was not adjusted in any way. Its total organic carbon (TOC) content was determined using a Shimadzu TOC-5000A analyser. The characteristics of the effluent were as follows: Chemical Oxygen Demand (COD) $=65 \mathrm{mg} / \mathrm{l}$, biochemical Oxygen Demand $\left(\mathrm{BOD}_{5}\right)=3 \mathrm{mg} / \mathrm{l}, \mathrm{pH}=6.6$, conductivity $=3.45 \mathrm{mS} / \mathrm{cm}$, Total Suspended Solids $(\mathrm{TSS})=76 \mathrm{mg} / \mathrm{l}$, amount of anions: $\mathrm{NO}^{2-}=0.58 \mathrm{ppm}$ and $\mathrm{NO}^{3-}=9.64 \mathrm{ppm}$ and amount of cations: $\mathrm{NH}_{4}{ }^{+}$and $\mathrm{Na}^{+}$below the detection limit.

\subsection{Adsorbents. Preparation of waste tyre activated carbons.}

The activated carbons (ACs) were obtained by means of pyrolysis in a rotary oven, as explained in a previous paper and then subjected to physical activation in the same oven at $850 \stackrel{\circ}{\circ}$ at a $\mathrm{CO}_{2}$ flow rate of $250 \mathrm{ml} / \mathrm{min}$ up to 36 or $66 \%$ burn-off (B.O.), expressed on an ashfree basis (Acevedo et al., 2013, Acevedo and Barriocanal, 2015).. The wastes used as raw materials for the production of the ACs were the reinforcing fibres (RF) obtained from ground end-of-life tyres and a 1:1 blend of RF with a low-rank bituminous coal (RF/Coal). Each AC was labelled with the name of the precursor followed by a number which represents the percentage of burn-off (e.g. RF36). If the AC had been acid treated, tr was also added to the label. 
2.3 Modification of the surface chemistry of the activated carbons.

The oxidation treatment was carried out in two consecutive steps. First the ACs were agitated at $40 \stackrel{\circ}{\circ}$ for $1 \mathrm{~h}$ in a solution of $6 \mathrm{M} \mathrm{HCl}$, after which they were washed with distilled water until neutral $\mathrm{pH}$. They were then stirred in a $6 \mathrm{M} \mathrm{HNO}_{3}$ solution at $75^{\circ} \mathrm{C}$ for $3 \mathrm{~h}$. As a final step, the samples were washed again with distilled water until neutral $\mathrm{pH}$.

\subsection{Characterization of the activated carbons.}

The textural properties of the ACs were studied by means of $\mathrm{N}_{2}$ adsorption at $77 \mathrm{~K}$ in a Micromeritics ASAP 2420 apparatus. The software package provided with the equipment was used to determine the BET surface area (SBET) employing a multipoint BET measuring method. The total pore volume $(\mathrm{Vt})$ was calculated from the nitrogen uptake at $\mathrm{p} / \mathrm{p} 0=0.97$. The micropore volume (Vmicro(Dub)) was determined by applying the Dubinin-Radushkevich equation to the lower relative pressure zone of the isotherm. The mesopore volume (Vmeso) was calculated by subtracting the micropore volume from the total pore volume. The samples were degasified under vacuum at $200{ }^{\circ} \mathrm{C}$ for $12 \mathrm{~h}$ prior to $\mathrm{N} 2$ adsorption to eliminate any moisture and condensed volatiles. The surface topography of the char and activated carbons before and after acid treatment was studied using a FEI QUANTA FEG 650 scanning electron microscope.

Temperature programmed desorption (TPD) analyses were carried out in an Altamira Instruments AMI-300 apparatus fitted with a Dymaxion Dycor mass spectrometer to analyse the amounts of $\mathrm{CO}$ and $\mathrm{CO}_{2}$ evolved from the decomposition of the surface oxygenated groups. The following masses were monitored: $2\left(\mathrm{H}_{2}\right), 18\left(\mathrm{H}_{2} \mathrm{O}\right), 28(\mathrm{CO})$ and $44\left(\mathrm{CO}_{2}\right)$.

To determine the $\mathrm{pH}$ at the point of zero charge $\left(\mathrm{pH}_{\mathrm{PzC}}\right)$ mixtures of each $\mathrm{AC}$ with solutions of $\mathrm{NaCl} 0.01 \mathrm{M}$ were prepared with different initial values of $\mathrm{pH}$. The $\mathrm{pH}_{\mathrm{PzC}}$ of each sample was determined from the intersection of the curve final $\mathrm{pH}$ vs. initial $\mathrm{pH}$ curve with the final pH = initial pH (Faria et al., 2004).

\subsection{Batch adsorption experiments.}

The rate of adsorption and the time required to reach equilibrium depend greatly on the particle size of the adsorbent. The activated carbon samples were finely ground to a particle size of less than $50 \mu \mathrm{m}$. Preliminary tests were carried out in order to determine the time required to reach equilibrium, which was $48 \mathrm{~h}$ for all the samples. Moreover, preliminary tests were also conducted in order to establish the appropriate initial dye concentration for studying the behaviour of the ACs. The adsorption equilibrium isotherms corresponding to each dye on the different AC samples were obtained as follows: $50 \mathrm{ml}$ of dye solution, with an initial concentration of between 12 and $1000 \mathrm{mg} / \mathrm{l}$ for Basic Astrazon Yellow 7GLL (AY) and of between 6 and $480 \mathrm{mg} / \mathrm{l}$ for Reactive Rifafix Red 3BN (RR), were mixed with $50 \mathrm{mg}$ of finely ground adsorbent in closed $100 \mathrm{ml}$ vessels. The vessels were wrapped in aluminium foil to 
prevent the light from degrading the dye, and then placed in a swaying shaker at room temperature until equilibrium was reached. The liquid was separated from the solid by centrifugation, and the remaining concentration of dye in solution was determined by means of a UV-Vis absorption spectrophotometer (U-2800A, Hitachi). Before the adsorption experiments, the initial $\mathrm{pH}$ was adjusted to 2, 7 and 12 using $\mathrm{HCl} 0.1 \mathrm{M}$ and $\mathrm{NaOH} 0.1 \mathrm{M}$. In all cases, blank tests in the absence of the adsorbent were carried out to evaluate the possibility of the dye being removed by other mechanisms (e.g. photochemical action), but the results were negative.

\section{Results and discussion}

3.1 Textural characteristics and surface chemistry of the activated carbons

It is known that textural characteristics vary as a function of the precursor and the degree of burn-off. Table 1 shows the textural characteristics of the activated carbons prepared by co-pyrolysis of the reinforcing fibre and coal at two burn-off degrees. It can be seen that $\mathrm{RF} /$ Coal36 and RF/Coal66 have higher surface areas ( $\mathrm{S}_{\mathrm{BET}}=522$ and $1126 \mathrm{~m}^{2} / \mathrm{g}$ respectively) than those prepared with only $R F\left(S_{B E T}=108\right.$ and $392 \mathrm{~m}^{2} / \mathrm{g}$ respectively). The mesopore volume of the ACs prepared from RF is higher and represents 67 and $84 \%$ of the total pore volume. The ACs with higher B.O. also show high pore volumes and surface areas. The percentage of B.O. was chosen on the basis of the results of a previous study on the activation process (Acevedo and Barriocanal 2015). The effect of acid treatment on the textural characteristics was not very significant. Only slight increases in surface area were observed possibly due to the fact that the pore entrances were blocked by ash. Functional groups formed on the carbon surface may also have prevented access to the $\mathrm{N}_{2}$ molecules (Table 1) (Órfão et al., 2006).

Scanning Electron Microscopy (SEM) was used to study the topography of the samples. Figure 1 compares the char prepared from the RF/Coal blend (Figure 1a) with the AC prepared to two levels of burn-off (Figure 1b, 1c) and the most activated AC after acid treatment (Figure 1d). Textural development is clearly observed as the B.O. increases, but, no clear differences due to acid treatment are appreciated.

On the other hand the surface chemistry of ACs is greatly modified due to the effect of the acids and the consequent increase in oxygen content. TPD provides information about the thermal stability of the functional groups present on the carbon surface. Although there is controversy as to the assignment of the different peaks in $\mathrm{CO}$ and $\mathrm{CO}_{2}$ spectra some general trends have been established in the literature. The procedure described by Figueiredo has been used in the present research work to evaluate the TPD results (Figueiredo et al., 1999, 2007). Figure 2 shows the evolution of the $\mathrm{CO}$ and $\mathrm{CO}_{2}$ for both the acid treated and the nontreated ACs. The $\mathrm{CO}_{2}$ curves corresponding to the ACs that were not acid-treated show a 
lower degree of functionalization, although carboxylic acids (200-450 ${ }^{\circ} \mathrm{C}$ ) and lactones (715$798^{\circ} \mathrm{C}$ ) are present (Figueiredo et al., 2007). The oxidized ACs have more carboxylic acids, as can be appreciated from the peaks with maxima in the temperature range between 217 and $235 \stackrel{\circ}{\circ}$ corresponding to strong acids and between 376 and $420{ }^{\circ} \mathrm{C}$ to weak acids. Moreover, anhydride groups are visible in the peak in the $603-667^{\circ} \mathrm{C}$ range. The curves that show the evolution of $\mathrm{CO}$ indicate differences in surface chemistry which is reflected in the peaks corresponding to $\alpha$-ketones/aldehydes (408-450 ${ }^{\circ} \mathrm{C}$ ), anhydrides, phenols (650-711 $\left.{ }^{\circ} \mathrm{C}\right)$ and carbonyl/quinone groups (814-947 $\left.{ }^{\circ} \mathrm{C}\right)$. These oxygen functionalities are present on the treated ACs whereas, the non-treated ACs generally have carbonyl/quinone groups.

As can be seen from Figure 2 the deconvolution of the curves fits the experimental data quite well. The results of the quantification of the $\mathrm{CO}$ and $\mathrm{CO} 2$ corresponding to each functional group are presented in Table 2. The amount of oxygen corresponding to the acid and basic surface groups together with the pHPZC is also shown in this Table.

Deconvolution of the $\mathrm{CO}$ and $\mathrm{CO} 2$ spectra reveals the contribution of the decomposition of the functional groups to each curve (Figure 2). The area under each curve provides a measure of the amount of the corresponding functional group depending on temperature (Table 2). As can be seen acid treatment apart from contributing to the creation of a greater variety of acid functional groups, leads to an increase in the amount of carboxylic (from 58-117 $\mu \mathrm{mol} \mathrm{g-1}$ to 241 and $1013 \mu \mathrm{mol} \mathrm{g} \mathrm{1,} \mathrm{Table} \mathrm{2)} \mathrm{and} \mathrm{phenol/ether} \mathrm{groups} \mathrm{(from} \mathrm{71-}$ $114 \mu \mathrm{mol} g-1$ to to $391-1103 \mu \mathrm{mol} \mathrm{g}-1$, Table 2$)$.

The response of the ACs differs depending on the precursor used. The samples prepared with coal are more susceptible to oxidation than those prepared with just RF and they have a larger amount of acid surface groups (3340 and $4056 \mu \mathrm{mol} \mathrm{O} \mathrm{g}{ }^{-1}$ for RF/Coal36tr and RF/Coal66tr, vs. 1201 and $1868 \mu \mathrm{mol} \mathrm{O} \mathrm{g}{ }^{-1}$ for RF36tr and RF66tr; Table 2). When RF is used as raw material, the ACs will contain a certain amount of carbon black from the original tyres, which will be lower in the ACs prepared from the blend with coal. Carbon black is less susceptible to oxidation than the high volatile coal used in the blends.

The $\mathrm{pH}_{\mathrm{PzC}}$ values obtained (Table 2) are related to the percentage of basic and acid groups on the $A C$ surface. The $\mathrm{pH}_{\mathrm{PzC}}$ value of the treated ACs is lower than 7 which is in agreement with the larger amount of acidic groups on the surface (approximately $>80 \%$ ). On the other hand the non-treated ACs show a high percentage of basic groups (approximately $>50 \%$ ) and a pH PzC value higher than 7 due to the larger amount of quinone groups. Apart from basic functional groups, delocalized $\pi$ electrons present on the basal planes also contribute to the basicity of ACs (Boehm, 1994, 2002; Fuente et al., 2003; Lahaye, 1998).

3.2 Dye removal by treated and non-treated ACs

Figure 3 shows the removal of reactive dye (RR) and basic dye (AY) from a solution with an initial concentration of $300 \mathrm{ppm}$ and a $\mathrm{pH}=7$. All the $\mathrm{ACs}$ are able to eliminate the basic 
dye very efficiently. In general reactive dyes are difficult to eliminate from a water solution due to their solubility (Al-degs et al., 2000; Willmott et al., 1998).

As the polarity of both dyes is different comparison of the dye elimination should be carried out in terms not only of surface chemistry and texture but also $\mathrm{pH}$. The ACs prepared from RF (both acid treated and non-treated) remove the reactive dye (which is anionic) more effectively than those prepared with the RF/Coal blend. Consequently texture here is more important than surface chemistry. The ACs prepared by blending with coal have higher surface areas but lower mesopore/total pore volume ratios than those prepared with only RF. The fact that the AC RF66 adsorbs a larger amount of dye than AC RF36 confirms that the mesopore volume is the determining factor for the elimination of the reactive dye. If ACs with a similar texture are compared, it can be seen that dye removal is more effective in the case of nontreated ACs because the $\mathrm{pH}_{\mathrm{PZC}}$ value is higher than 7 and the carbon surface I be is positively charged.

In the case of the basic dye better results can be expected using treated ACs because the $\mathrm{pH}_{\mathrm{PzC}}<\mathrm{pH}_{\text {solution }}$ and the surface of the activated carbon is negatively charged as a results of which a large number of sites is available for the adsorption of the basic dye due to electrostatic interactions. Figure 3 shows that the best adsorption results correspond to the non-treated ACs that have basic surface functional groups. Another adsorption mechanism involving dispersive interactions between free electrons from aromatic rings and double bonds of dye molecules and delocalized $\pi$ electrons in the basal planes of the carbon material may also play a role (Pereira et al., 2003; Radovic et al., 1997). In the case of the adsorption of the cationic dye by RF/Coal66 ( $\left.\mathrm{S}_{\mathrm{BET}}=1126 \mathrm{~m}^{2} / \mathrm{g}\right)$ and RF66 $\left(\mathrm{S}_{\mathrm{BET}}=392 \mathrm{~m}^{2} / \mathrm{g}\right)$ texture may also be important due to the removal of more dye in the case of RF/Coal66. However, it needs to be borne in mind that, although both have a pH Pzc greater than 7, that of RF66 is higher, which suggests that its surface will have more positively charged sites with the consequent disadvantage of electrostatic interactions. The only treated $A C$ that shows basic dye removal percentages similar to those of the non-treated ACs is RF/Coal66tr. In this case, apart from its large surface area, the AC has experienced the largest increase in oxygenated acid functional groups due to acid treatment. It therefore has more sites available for electrostatic interaction with cations from the basic dye.

ACs are amphoteric materials. Therefore their surface can be either negatively or positively charged as function of the $\mathrm{pH}$ of the solution and this also has an influence on the electrostatic interactions. Figures 4 and 5 show the adsorption isotherms of the reactive and basic dyes respectively at three pHs i.e. 2, 7 and 12 . The adsorption of the anionic reactive dye (Figure 4) is generally favored at $\mathrm{pH}=2$. When the $\mathrm{pH}_{\text {solution }}<\mathrm{pH}$ PzC, the carbon surface is positively charged, whereas the adsorption of the cationic dye is favored at basic pH (Figure 5) because, when $\mathrm{pH}>\mathrm{pH}_{\mathrm{PzC}}$, the carbon surface will be negatively charged. 
The Langmuir model, which assumes monolayer coverage and that all sites on the surface are equivalent, was used to fit the experimental data. The fitting was considered correct since $R^{2}$, in general, is greater than 0.99. This model indicates that there is no strong competition between the solvent and the adsorbate for occupying the sites on the carbon surface.

The values of maximum removal $\left(q_{\max }\right)$ in the case of the basic dye are higher at $\mathrm{pH}=7$ (567-91 mg/g) and $12(1055-70 \mathrm{mg} / \mathrm{g})$ compared to values found in the literature for the adsorption of the same dye using different adsorbents: $82 \mathrm{mg} / \mathrm{g}$ (Sahmounea and Ouazene, 2012), 62 - $88 \mathrm{mg} / \mathrm{g}$ (Tekbaş et at., 2009), 69 - $92 \mathrm{mg} / \mathrm{g}$ (Sulak et al., 2007). On the other hand the $q_{\max }$ values of the reactive dye $(122 \mathrm{mg} / \mathrm{g}$ at $\mathrm{pH}=2)$ are lower than the values found in the literature (Figueiredo et al., 2011; Órfão et al., 2006).

The most effective AC for the reactive dye is RF66 while in the case of the basic dye $\mathrm{RF} /$ Coal66 is the best performer.

In order to determine the best adsorbent of the dye mixture, a 1:1 solution was prepared. Figure 6 shows the UV-VIS spectra corresponding to the solution of the mixture (300 mg/l, pH=7) and after adsorption using the two best ACs.

In the spectrum of the mixture two peaks corresponding to the individual dyes are observed, at $542 \mathrm{~nm}$ and $418 \mathrm{~nm}$ corresponding to the reactive and basic dye respectively. After the adsorption it is evident that both ACs successfully eliminated the basic dye from solution with a removal efficiency of $92 \%$ in the case of RF/Coal66 and $86 \%$ for RF66. In contrast, the removal of the reactive dye was lower with an efficiency of only $25 \%$ for RF66 and $4 \%$ with RF/Coal66. On the whole, RF66 proved to be the best adsorbent of the dye mixture.

The two ACs that showed the best adsorption results i.e. RF66 y RF/Coal66 were used to treat a real textile effluent which apart from dyes contained metals, oils, salts etc. In general the $\mathrm{pH}$ of a textile effluent is alkaline because of the large amount of salts (Kuhad et al., 2004; Ottoni et al., 2013). In the present research work, the $\mathrm{pH}$ of the textile effluent was neutral since the effluent was collected after being biologically treated in a wastewater treatment plant. Consequently, leaching of inorganic impurities from the activated carbons was not considered to be a problem due to the scarcity of most inorganic species in neutral or alkaline conditions (San Miguel et al., 2002).

Figure 7 shows the spectra of the textile effluent before and after treatment with the two ACs. The absorption results for the dyes are similar in both cases except for the removal of organic carbon. Table 4 shows that RF66 is clearly more efficient than RF/Coal66 in reducing TOC $(88 \%$ vs. $32 \%)$.

\section{Conclusions}


ACs prepared with a blend of RF and coal had the highest $S_{B E T}$ with values of up to $1253 \mathrm{~m}^{2} / \mathrm{g}$, whereas those prepared with RF exhibited the highest mesopore volume $\left(0.30 \mathrm{~cm}^{3} / \mathrm{g}\right)$. Modification of their texture due to acid treatment was only slight, but their surface chemistry was modified considerably with significant increases in the amount of acid groups, especially in the ACs prepared with coal.

An adsorption test highlighted the different behaviours of the two dyes. The texture of the ACs and more specifically their mesopore volume were the most important parameter affecting the adsorption of the reactive dye, whereas surface chemistry and dispersive interactions were more influential for the adsorption of the basic dye.

RF66 and RF/Coal66 were the activated carbons that showed the highest adsorption capacity. Of these two, RF66 was better as adsorbent for the dye mixture and for tackling a real industrial effluent; possibly because, although it had a smaller $\mathrm{S}_{\mathrm{BET}}$, it had a larger mesopore volume.

\section{Acknowledgements}

The research leading to these results has received funding from the Spanish MICINN CTM2009-10227, and was co-financed by FCT/MEC and FEDER under Program PT2020 (Project UID/EQU/50020/2013) and by QREN, ON2 and FEDER (Project NORTE-07-0124FEDER-000050). B. Acevedo thanks the Government of the Principado the Asturias for the award of a predoctoral grant with funds from the PCTI Asturias. R.P. Rocha acknowledges grant SFRH/BD/95411/2013 from Fundação para a Ciência e a Tecnologia (FCT).

\section{References}

Acevedo, B., Barriocanal, C., Álvarez, R., 2013. Pyrolysis of blends of coal and tyre wastes in a fixed bed reactor and a rotary oven. Fuel 113, 817-825.

Acevedo, B., Barriocanal, C., 2015. Texture and surface chemistry of activated carbons obtained from tyre wastes. Fuel Proc. Technol. http://dx.doi.org/10.1016/j.fuproc.2015.02.009 Acevedo, B., Fernández, A.M., Barriocanal, C., 2015. Identification of polymers in waste tyre reinforcing fibre by thermal analysis and pyrolysis. J. Anal. Appl. Pyrolysis 111, 224-232.

Al-degs, Y., Khraisheh, M.A.M., Allen, S.J., Ahmad, M.N., 2000. Effect of carbon surface chemistry on the removal of reactive dyes from textile effluent. Wat. Res. 34, 927-935.

Boehm, H.P., 1994. Some aspects of the surface chemistry of carbon blacks and other carbons, Carbon 32, 759-769. 
Boehm, H.P., 2002. Surface oxides on carbon and their analysis: a critical assessment. Carbon 40, 145-149.

Cardoso, N.F., Lima, E.C., Pinto, I.S., Amavisca, C.V., Royer, B., Pinto, R.B., Alencar, W.S., Pereira, S.F.P., 2011. Application of cupuassu Shell as biosorbent for the removal of textile dyes from aqueous solution. J. Environ. Manage. 92, 1237-1247.

Ciardelli, G., Corsi, L., Marucci, M., 2000. Membrane separation for wastewater reuse in the textile industry. Resources Conservation Recycling. 31, 189-197.

Fang, R., Cheng, X.S., Xu, X.R., 2010. Synthesis of lignin-base cationic flocculant and its application in removing anionic azo-dyes from simulated wastewater. Bioresour. Technol. 101, 7323-7329.

Faria, P.C.C., Órfão, J.J.M., Pereira, M.F.R., 2004. Adsorption of anionic and cationic dyes on activated carbons with different surface chemistries. Water Research 38, 2043-2052.

Ferrero, F., 2000. Oxidative degradation of dyes and surfactant in the Fenton and photoFenton treatment of dyehouse effluents. J. Soc. Dyers Colour. 116, 148-153.

Figueiredo, J.L., Pereira, M.F.R., 2010. The role of surface chemistry in catalysis with carbons. Catalysis Today 150, 2-7.

Figueiredo, J.L., Pereira, M.F.R., Freitas, J.J.M., Órfão, J.J.M., 1999. Modification of the surface chemistry of activated carbons. Carbon 37, 1379-1389.

Figueiredo, J.L., Pereira, M.F.R., Freitas, M.M.A., Órfão, J.J.M., 2007. Characterization of active sites on carbón catalysts. Ind.Eng.Chem.Res. 46, 4110-4115.

Figueiredo, J.L., Sousa, J.P.S., Orge, C.A., Pereira, M.F.R., Órfão, J.J.M., 2011. Adsorption of dyes on carbon xerogels and templated carbons: influence of surface chemistry. Adsorption $17,431-441$

Fuente, E., Menéndez, J. A., Suárez, D., Montes-Morán, M. A., 2003. Basic Surface Oxides on Carbon Materials: A Global View. Langmuir 19, 3505-3511.

Giles, C.H., MacEwan, T.H., Nakhwa, S.N., Smith, D., 1960. Studies in adsorption. XI. A system of classification of solution adsorption isotherms, and its use in diagnosis of adsorption mechanisms and in measurements of specific surface areas of solids, J. Chem. Soc. 10, 39733993.

Gupta, V.K., Gupta, B., Rastogi, A., Agarwal, S., Nayak, A., 2011. A comparative investigation on adsorption performances of mesoporous activated carbon prepared from waste rubber tire and activated carbon for a hazardous azo dye-Acid Blue 113. J. Hazard. Materials. 186, 891901.

Hsu, Y., Chen, J., Yang, H., Chen, J., 2001. Decolorization of dyes using ozone in a gasinduced reactor. AIChE J. 47, 169-176. 
Kuhad, R.C., Sood, N., Tripathi, K.K., Singh, A., Ward, O.P., 2004. Developments in microbial methods for the treatment of dye effluents. Adv. Appl. Microbiol 56, 185-213.

Kyotani, T., Karasawa, S., Tomita, A., 1986. A TPD study of coal chars in relation to the catalysis of mineral matter. Fuel 65, 1466-1469.

Lahaye,J., 1998. The chemistry of carbon surfaces. Fuel 77, 543-547.

Marchon, B., Carrazza., J., Heinemann, H., Somorjai, G.A., 1988. TPD and XPS studies of $\mathrm{O} 2, \mathrm{CO} 2$, and $\mathrm{H} 2 \mathrm{O}$ adsorption on clean polycrystalline graphite. Carbon $26,507-514$.

Nigam, P., Armour, G., Banat, I.M., Singh, D., Marchant, R.,2000. Physical removal of textile dyes and solid state fermentation of dye-adsorbed agricultural resides. Bioresour.Technol. 72, 219-226.

Órfão, J.J.M., Silva, A.I.M., Pereira, J.C.V., Barata, S.A., Fonseca, I.M., Faria, P.C.C., Pereira, M.F.R., 2006. Adsorption of a reactive dye on chemically modified activated carbons-Influence of pH. J. Colloid. Inter. Sci. 296, 480-489.

Ottoni, C. A., Santos, C., Kozakiewicz, Z., Lima, N., 2013. White-rot fungi capable of decolourising textile dyes under alkaline conditions. Folia Microbiol 58, 187-193.

Paschoal, F.M.M., Anderson, M.A., Zanoni, M.V.B, 2009. The photoelectron-catalytic oxidative treatment of textile wastewater containing disperse dyes. Desalination 249, 1350-1355.

Peng, X., Huang, D., Odoom-Wubah, T., Fu, D., Huang, J., Qin, Q., 2014. Adsorption of anionic and cationic dyes on ferromagnetic ordered mesoporous carbon from aqueous solution: Equilibrium, thermodynamic and kinetics. Journal of Colloid and Interface Science 430, $272-282$.

Pereira, M.F.R., Soares, S. F., Órfão, J.J.M., Figueiredo, J.L., 2003. Adsorption of dyes on activated carbons: influence of surface chemical groups. Carbon 41, 811-821.

Perkins, W.S., Walsh, W.K., Reed, I.E., Namboodri, C.G., 1995. A demonstration of reuse of spent Dyebath water following color removal with ozone. Textile Chem. Colorist. 28, 31-37.

Prola, L.D.T., Acayanka, E., Lima, E.C., Umpierres, C.S., Vaghetti, J.C.P., Santos, W.O., Laminsi, S., Djifon, P., 2013. Comparison of Jatropha curcas shells in natural form and treated by non-thermal plasma as biosorbents for removal of Reactive Red 120 textile dye from aqueous solution. Ind.Crop.Prod. 46, 328-340.

Radovic, L.R., Silva, I.F., Ume, J.I., Menéndez, J.A., Leon y Leon C.A., Scaroni, A.W., 1997. An experimental and theorical study of the adsorption of aromatics possessing electronwithdrawing and electron-donating functional groups by chemically modified activated carbons. Carbon 34, 1339-1348. 
Robinson, T., McMullan, G., Marchant, R., Nigam, P., 2001. Remediation of dyes in textile effluent: a critical review on current treatment technologies with a proposed alternative. Bioresour.Technol. 77, 247-255.

Sahmounea M. N., Ouazeneb, N.,2012. Mass-Transfer Processes in the Adsorption of Cationic Dye by Sawdust. Environmental Progress \& Sustainable Energy 31, 597-603.

San Miguel G., Fowler G.D., Sollars C.J., 2002. The leaching of inorganic species from activated carbons produced from waste tyre rubber. Water Research 36, 1939-1946.

Schoonen M.A. Schoonen J.M.T., 2014. Removal of crystal violet from aqueous solutions using coal. J. Colloid and Interface Sci.422, 1-8.

Srinivasan, A., Viraraghavan, T., 2010. Decolorization of dye wastewaters by biosorbents:a review. J. Environ. Manage. 91, 1915-1929.

Sulak, M. T., Demirbas, E., Kobya, M., 2007. Removal of Astrazon Yellow 7GL from aqueous solutions by adsorption onto wheat bran. Bioresource Technology 98, 2590-2598.

Tekbaş, M., Bektaş,N., Yatmaz, H.C., 2009. Adsorption studies of aqueous basic dye solutions using sepiolite. Desalination 249, 205-211.

Weber, E., Wolfe, N.L., 1987. Kinetics studies of reduction of aromatic azo compounds in anaerobic sediment/water systems. Environ. Toxicol.Chem. 6, 911-920.

Willmott, N., Guthrie, J., Nelson, G., 1998. The biotechnology approach to colour removal from textile effluent. JSDC 114, 38-41.

Zielke, U., Hüttinger, K.J., Hoffman, W.P., 1996. Surface-oxidized carbon fibers: I. Surface structure and chemistry Carbon 34, 983-998. 
Table 1. Textural Characteristics of ACs.

\begin{tabular}{lccccc}
\hline & $\begin{array}{c}\mathrm{S}_{\mathrm{BET}} \\
\left(\mathrm{m}^{2} / \mathrm{g}\right)\end{array}$ & $\begin{array}{c}\mathrm{V}_{\text {total }} \\
\left(\mathrm{cm}^{3} / \mathrm{g}\right)\end{array}$ & $\begin{array}{c}\mathrm{V}_{\text {micro }}(\mathrm{Dub}) \\
\left(\mathrm{cm}^{3} / \mathrm{g}\right)\end{array}$ & $\begin{array}{c}\mathrm{V}_{\text {meso }} \\
\left(\mathrm{cm}^{3} / \mathrm{g}\right)\end{array}$ & $\mathrm{V}_{\text {meso }} / \mathrm{V}_{\text {total }}$ \\
\hline RF 36 & $107.65 \pm 0.02$ & 0.26 & 0.04 & 0.22 & 0.84 \\
RF 66 & $392.46 \pm 0.92$ & 0.45 & 0.15 & 0.30 & 0.67 \\
RF Coal 36 & $521.87 \pm 1.11$ & 0.27 & 0.20 & 0.07 & 0.27 \\
RF Coal 66 & $1126.01 \pm 1.79$ & 0.59 & 0.39 & 0.21 & 0.35 \\
RF 36 tr & $132.82 \pm 0.22$ & 0.31 & 0.05 & 0.25 & 0.83 \\
RF 66 tr & $354.85 \pm 1.09$ & 0.40 & 0.14 & 0.26 & 0.66 \\
RF Coal 36 tr & $516.15 \pm 1.18$ & 0.25 & 0.20 & 0.06 & 0.22 \\
RF Coal 66 tr & $1253.18 \pm 1.81$ & 0.60 & 0.43 & 0.17 & 0.28 \\
\hline
\end{tabular}


Table 2. Amounts of $\mathrm{CO}_{2}$ and $\mathrm{CO}$ desorbed $\left(\mu \mathrm{mol} \mathrm{g} \mathrm{g}^{-1}\right)$ with corresponding oxygen in acid and basic surface groups $\left(\mu \mathrm{mol} \mathrm{O} \mathrm{g}^{-1}\right)$ and pH $\mathrm{pzc}$.

\begin{tabular}{|c|c|c|c|c|c|c|c|c|c|c|c|}
\hline & \multicolumn{4}{|c|}{$\mathrm{CO}_{2}$} & \multicolumn{4}{|c|}{$\mathrm{CO}$} & \multirow{2}{*}{$\begin{array}{l}\text { Oxygen } \\
\text { in Acid } \\
\text { Surface } \\
\text { Groups }\end{array}$} & \multirow{2}{*}{$\begin{array}{l}\text { Oxygen } \\
\text { in Basic } \\
\text { Surface } \\
\text { Groups }\end{array}$} & \multirow{2}{*}{$\mathrm{pH}_{\mathrm{PZC}}$} \\
\hline & $\begin{array}{l}\text { carboxylic } \\
\text { acids }\end{array}$ & $A^{a}$ & anhydride & lactones & $\begin{array}{l}\alpha \text {-ketones } \\
\text { /aldehydes }\end{array}$ & anhydride & $\begin{array}{l}\text { ether/ } \\
\text { phenol }\end{array}$ & $\begin{array}{l}\text { carbonyl/ } \\
\text { quinone }\end{array}$ & & & \\
\hline RF 36 & 58 & 107 & - & 49 & - & - & - & 634 & 215 & 634 & 9.6 \\
\hline RF 66 & 75 & 171 & - & 157 & - & - & - & 1218 & 464 & 1218 & 9.5 \\
\hline RFCoal 36 & - & 52 & - & 12 & 62 & - & 114 & 586 & 200 & 586 & 8.7 \\
\hline RF Coal 66 & 117 & 86 & - & 117 & 86 & - & 71 & 570 & 623 & 570 & 8.2 \\
\hline $\mathrm{RF} 36 \mathrm{tr}$ & 241 & - & 74 & 20 & 65 & 74 & 391 & 335 & 1201 & 335 & 4.2 \\
\hline RF $66 \mathrm{tr}$ & 445 & - & 114 & - & - & 114 & 638 & 219 & 1868 & 219 & 3.1 \\
\hline RFCoal $36 \mathrm{tr}$ & 861 & - & 228 & - & 98 & 228 & 835 & 597 & 3340 & 597 & 3.3 \\
\hline RF Coal 66 tr & 1013 & - & 261 & - & 145 & 261 & 1103 & 1004 & 4056 & 1004 & 4.6 \\
\hline
\end{tabular}

a. A represents the peaks identified in the TPD profiles of untreated samples at 552-600 ${ }^{\circ} \mathrm{C}$ and $617-646{ }^{\circ} \mathrm{C}$. These peaks are explained by interactions of the mineral matter content of these samples with carbon, as discussed in Kyotani et al., 1986. 
Table 3. Parameters of the Langmuir model for adsorption isotherms.

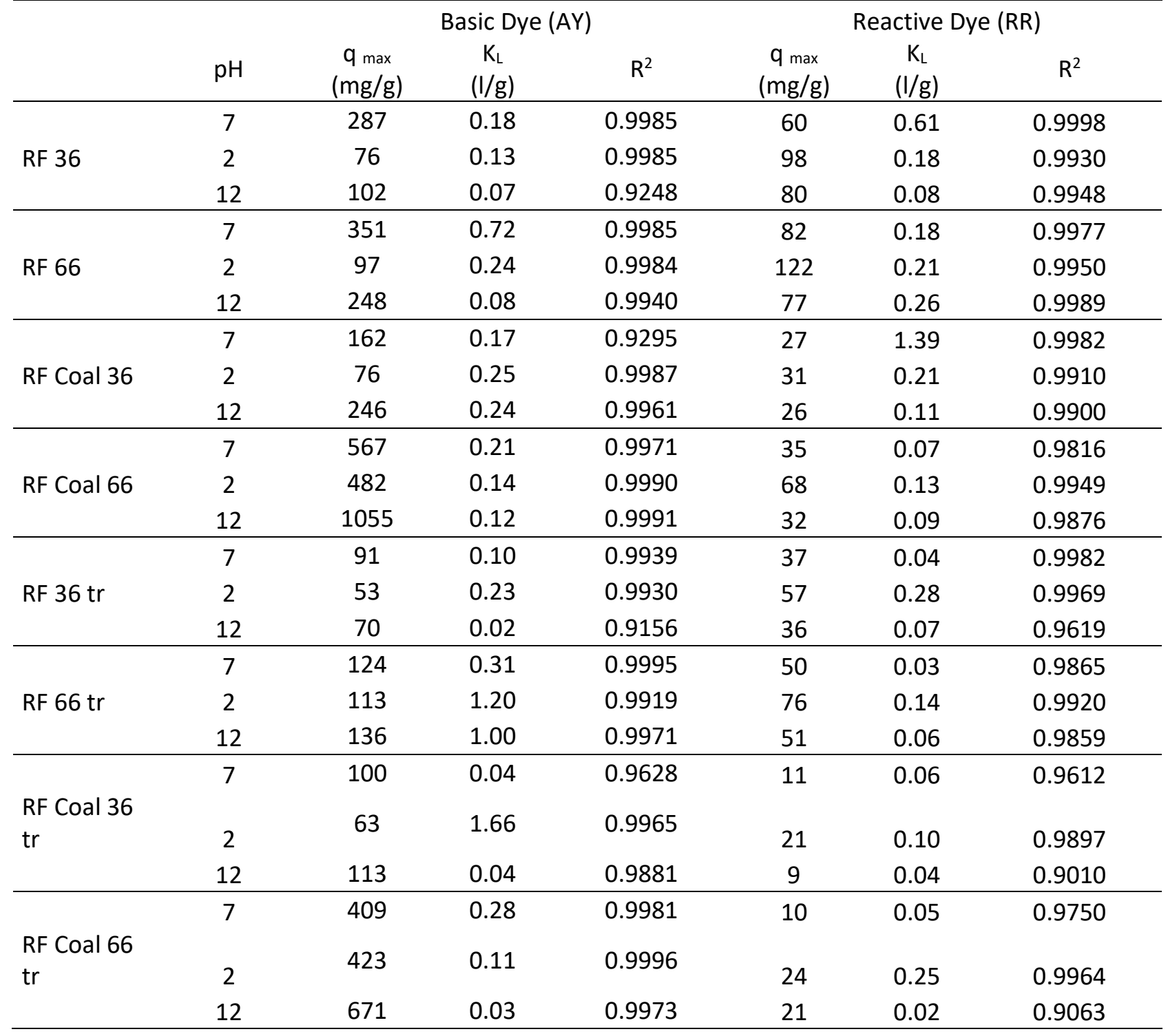


Table 4. TOC values of industrial effluent before and after adsorption.

\begin{tabular}{lccc}
\hline & $\begin{array}{c}\mathrm{TC}^{\mathrm{a}} \\
(\mathrm{ppm})\end{array}$ & $\begin{array}{c}\mathrm{IC}^{\mathrm{b}} \\
(\mathrm{ppm})\end{array}$ & $\begin{array}{c}\text { TOC } \\
(\mathrm{ppm})\end{array}$ \\
\hline Real Effluent & 133.8 & 118.7 & 15.1 \\
RF 66 & 105.2 & 103.4 & 1.8 \\
RF coal 66 & 113.4 & 103.1 & 10.3 \\
\hline
\end{tabular}

a TC: Total carbon

b. Inorganic carbon 


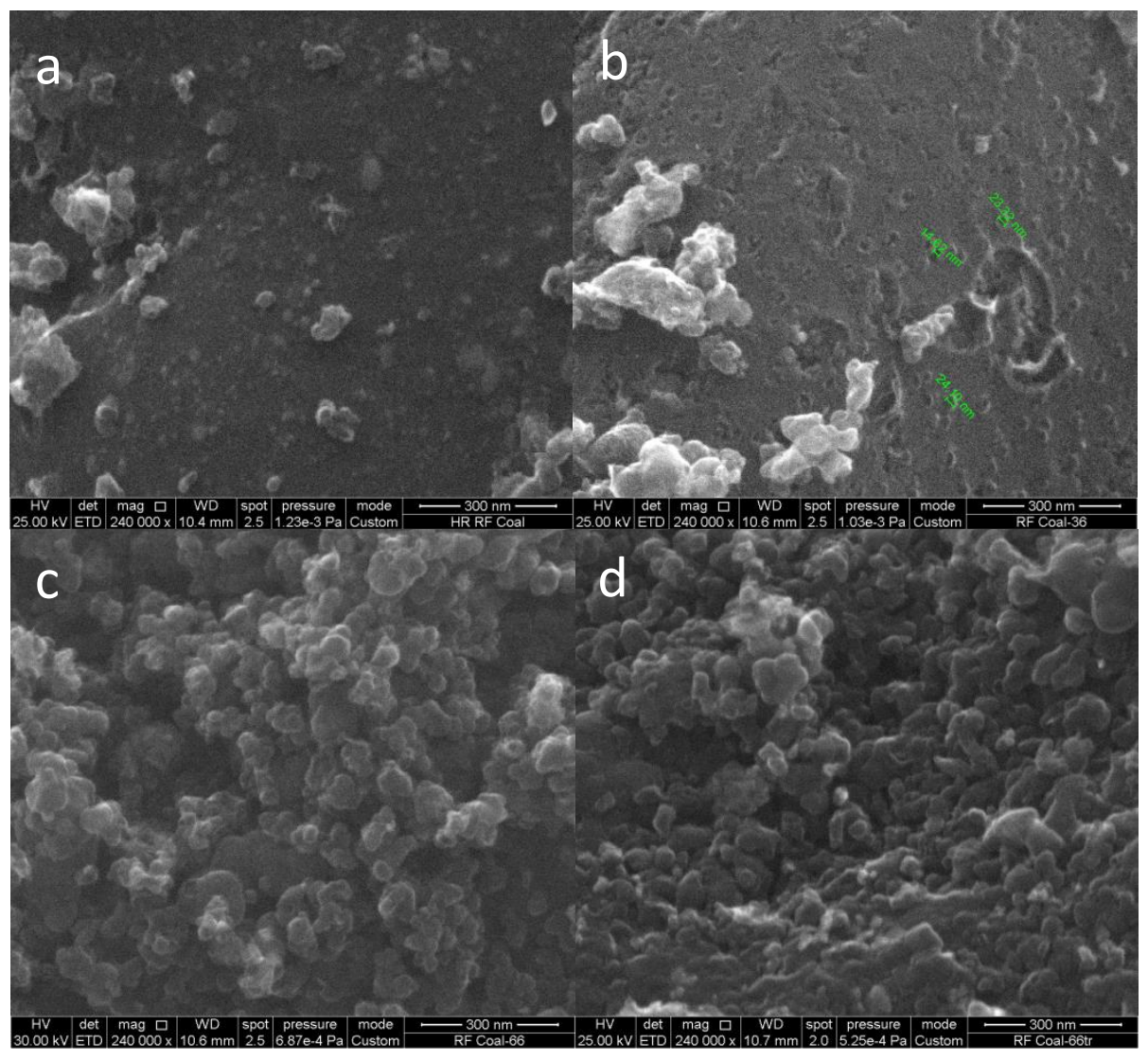

Figure 1. SEM images. a. RFCoal char, b. RFCoal 36, c. RF Coal 66 and d. RFCoal 66 tr. 

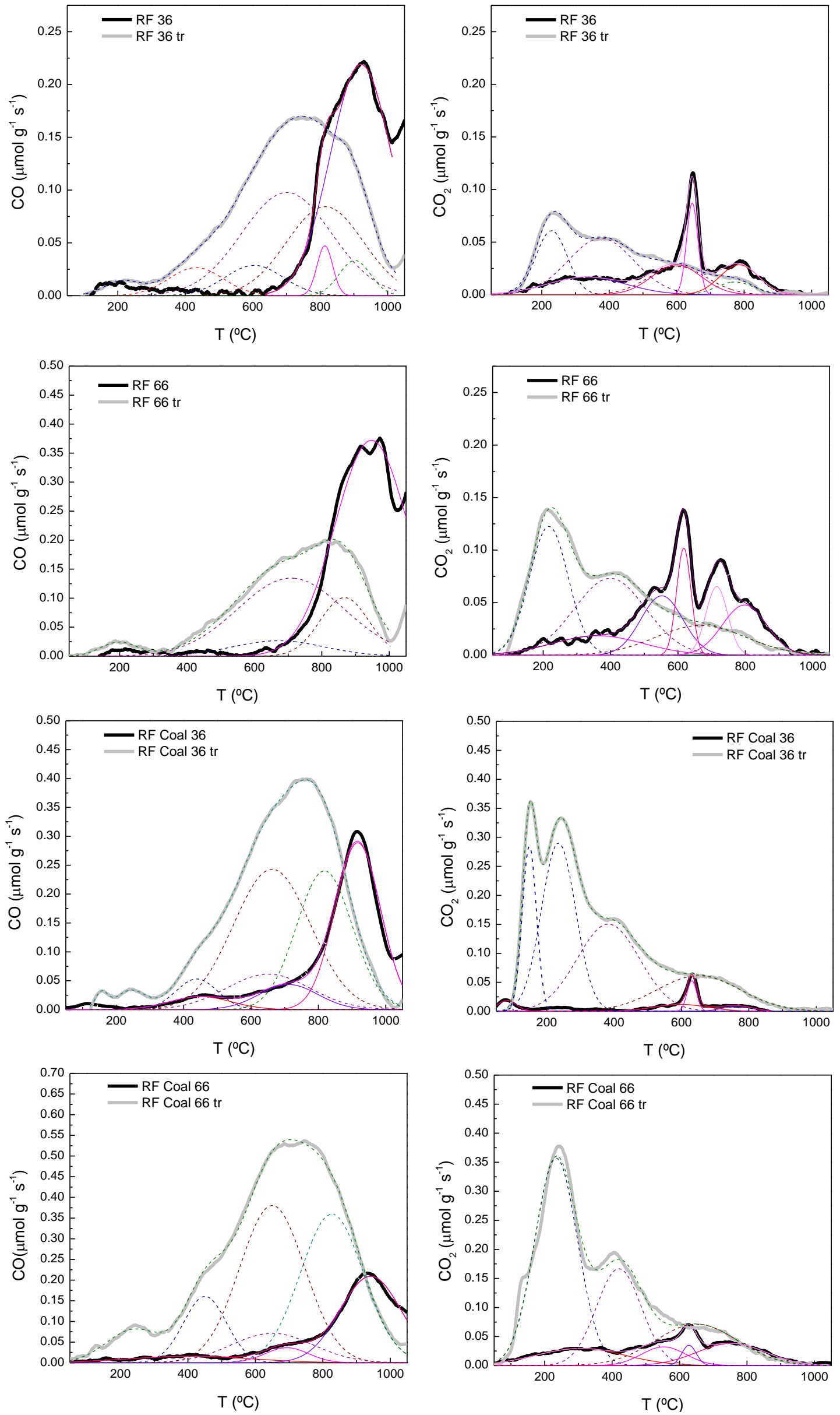

Figure 2. TPD spectra of activated carbon samples: (left) $\mathrm{CO}$ evolution and (right) $\mathrm{CO}_{2}$ evolution. 


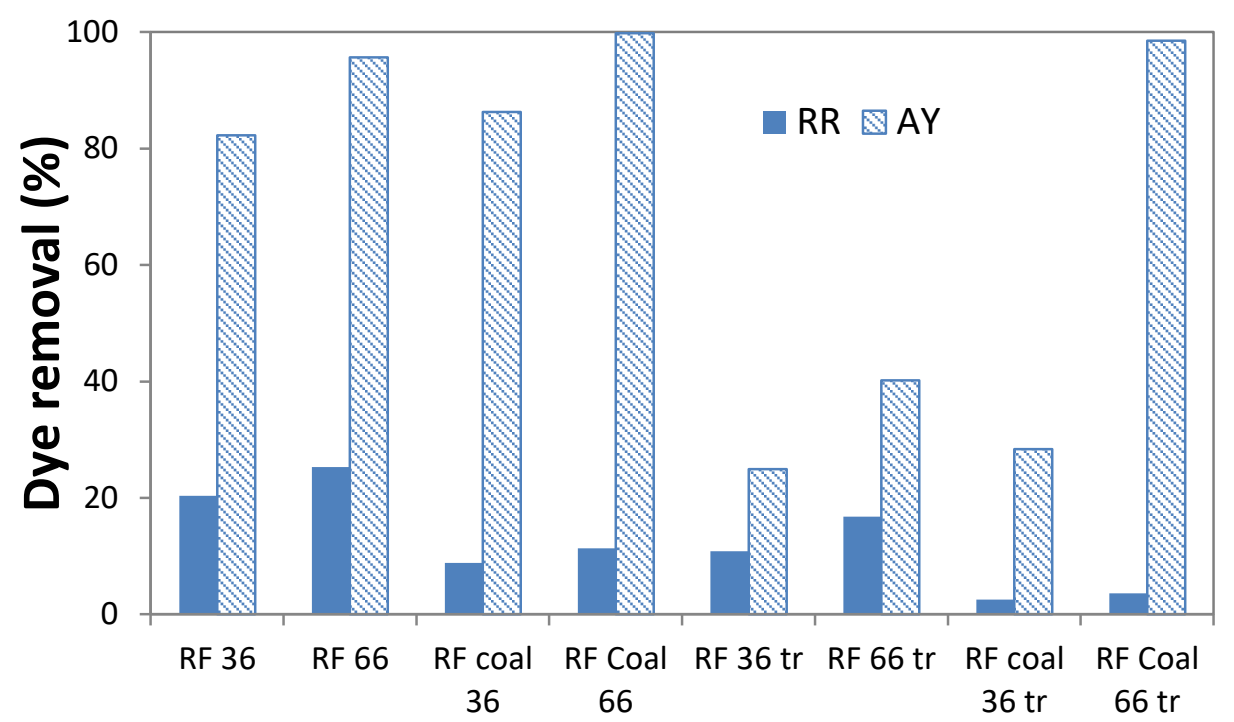

Figure 3. Dye removal by $\mathrm{ACs}$. $\mathrm{Co}=300 \mathrm{mg} / \mathrm{l}$ and $\mathrm{pH}=7$. 

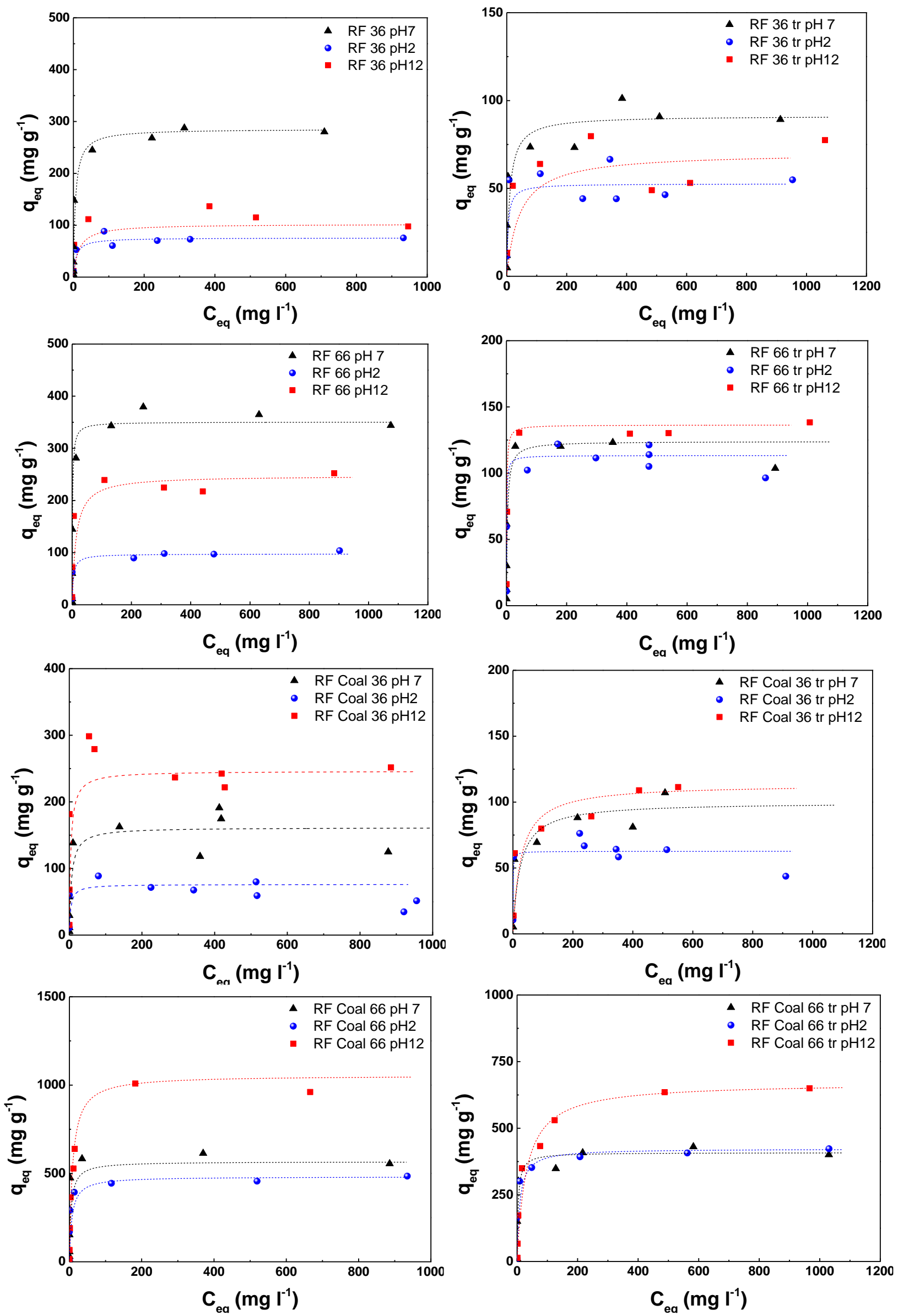

Figure 4. Adsorption Isotherms of the basic dye by ACs. 

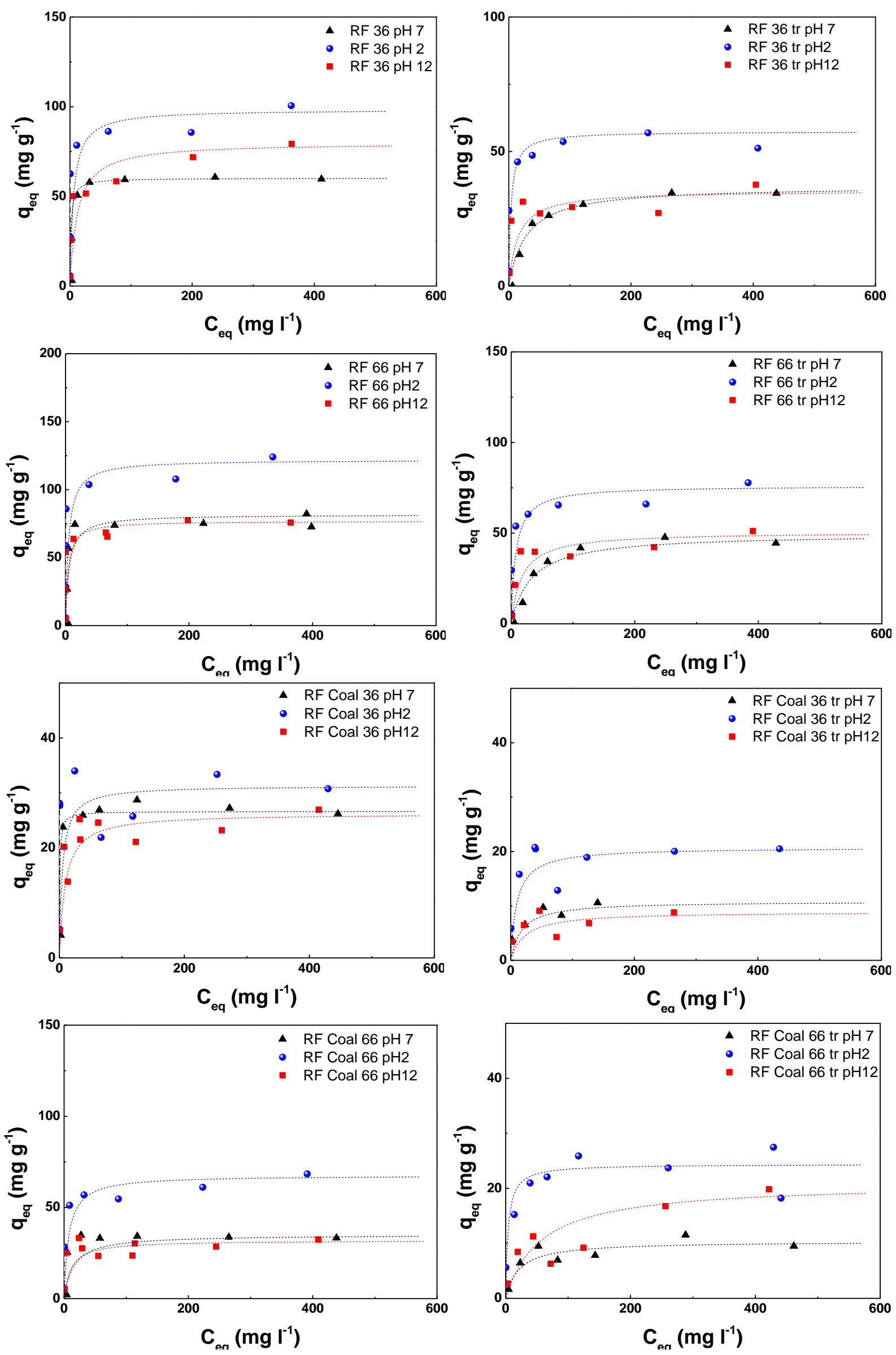

Figure 5. Adsorption Isotherms of the reactive dye by ACs. 


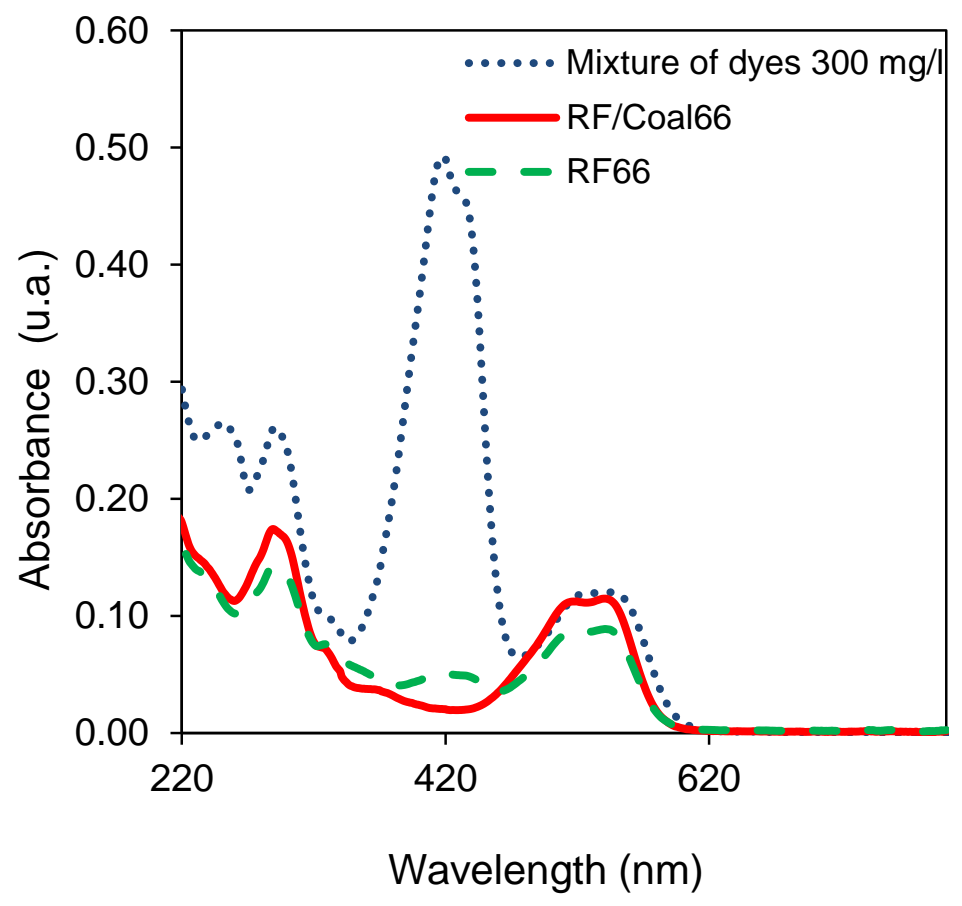

Figure 6. UV-Vis spectra for the mixture of commercial dyes before and after adsorption with RF Coal 66 and RF 66. Diluted $1 \times 20$. 


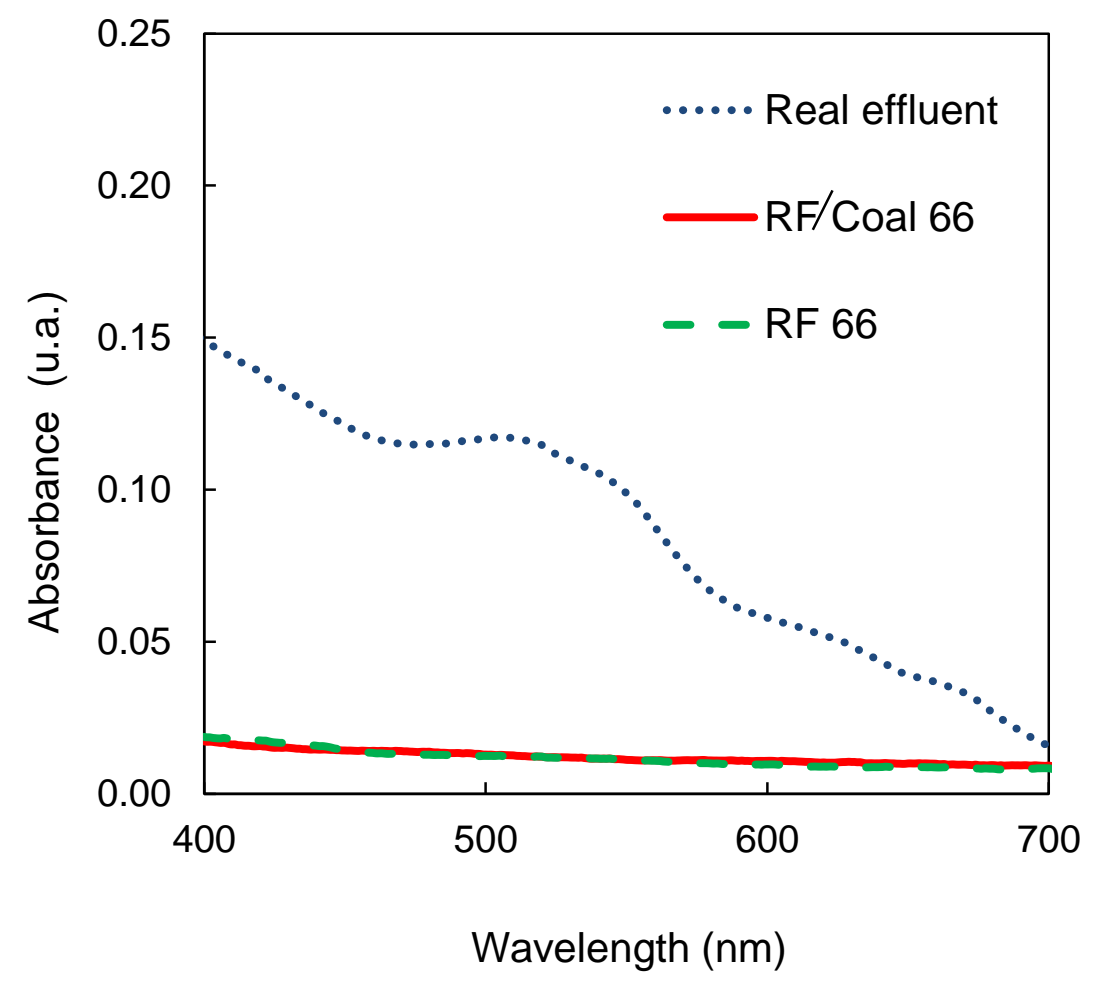

Figure 7. Visible spectra for the real textile effluent before and after adsorption with activated carbon samples (RF Coal 66 y RF 66). 